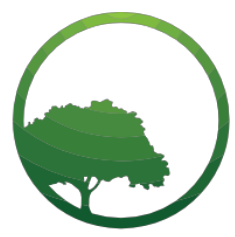

Business \& Social Science IJRBS

\section{Research in Business and Social Science}

IJRBS Vol 8 No 2, ISSN: 2147-4478

Contents available at www.ssbfnet.com/ojs

\title{
The Integration of Entrepreneurship Education in to Ethiopian Universities Formal Curriculum
}

\section{Wudu Melese Tarekegne}

Corresponding Author: Assistant professor, Jimma University, Department of Teacher Education and Curriculum Studies, Ethiopia. Tel. +251917800912

\section{Alebachew Hailu Gelaneh}

curriculum expert in Addis Ababa University, South compus, Ethiopia. Tel. 251924159858

\begin{abstract}
This study was aimed at investigating how Ethiopian universities integrate entrepreneurship education into the formal curriculum. To achieve this objective descriptive survey research design was used. Data were collected from university students, instructors, and department heads. Accordingly, four universities were selected as sample universities by using simple random sampling technique. From these sample universities departments that give entrepreneurship course with all its students, instructors and department heads were taken as sample of the study. Data were collected by using questionnaire, interview, and document analysis from the participants. The result shows that in Ethiopian higher education institutions, entrepreneurship education curriculum and teaching methods is developed in house; have no a formalized national or international exchange of good practice in entrepreneurship education and did not include entrepreneurs in the development of entrepreneurship teaching materials. In addition, since the entrepreneurship education course is not integrated to all programs only few students took it as a result students did not develop entrepreneurial behavior, skills, knowledge in their stay in the university. The predominant methods of teaching used were lecture and case study. The major barriers for the development of entrepreneurship education identified are lack of funding available to support the entrepreneurship education and good-quality entrepreneurship education materials, lack of support from the top management and lack of strategic integration of entrepreneurship education in their institutions.
\end{abstract}

Key words: Entrepreneurship education, University, Integration; Formal Curriculum

JEL classification: $A$ 20, A 21

Submitted: 14.02.2019 - Accepted: 02.03.2019

\section{Introduction}

By cognizant of the role entrepreneurship education for development as well as by taking into consideration the recommendations of some international organizations and global trends entrepreneurship education is suggested to be a component in higher education of Ethiopia. For instance, MOE (2008); MOE (2015) 
document clearly stated that all higher education institutions of Ethiopia should develop an entrepreneurial attitude on the part of its graduates which are necessary attributes for becoming a world class-university.

Similarly, Article 7 (d) of World Declaration in the development of higher education in Ethiopia, puts the significance of entrepreneurial education in developing economies thus: developing entrepreneurial skills and initiative should become major concerns of higher education in order to facilitate employability of graduates who will increasingly be called upon to be not only job seekers but also and above all to become job creators. (Ghelawdewos, 2012).

Research recognizes that courses or program in entrepreneurship can enhance participant intentions' to start a business as well us to develop entrepreneurial capabilities or to create more innovative or profitable ventures (Henry, Hill \& Letch, 2005), showing the significance of entrepreneurship education. In other words, entrepreneurship education is believed to have invariable result in a comparable growth in the quantity and quality of entrepreneurial activity.

There are different reasons why the government of Ethiopia promotes the provision of entrepreneurship education in higher education institutions. Currently, Ethiopia's higher education system generates a large number of graduates every year. However, its economy is not in a position to absorb the graduates passing out, leading to an increase in the educated unemployed. In recent years, Ethiopia's population has grown very fast. Because of the history of Ethiopia and its multi-cultural composition, it seems impossible to have a Family Planning policy like that of China in the near future. It is likely that Ethiopia's population will continue to grow, which will consequently worsen the employment situation.

In order to catch up with the pace of developed countries, Ethiopia needs many entrepreneurs willing to make their businesses bigger. If the university students with high entrepreneurial potentials get proper training, they will have the best prospects for becoming .real. entrepreneurs. Entrepreneurship is a matter that involves everyone the government, society, and the educational institutions. If Entrepreneurship Education (EE) in Ethiopia's higher education system cannot completely address major obstacles in the pursuit of national economic development and employment, at least it can offer a start.

The existing literature shows that there is a ample research on Entrepreneurship education in the USA, Europe, and even Asia. However, little is known about the nature of entrepreneurship education in Africa including in Ethiopia with the exception of some fragmented studies ( Isaacs et al., 2007; Brijlal, 2008; Co \& Mitchell, 2006). Hence, this study attempted to reveal the nature of integration of entrepreneurship education in higher education institutions formal curriculum system. To see this the following research questions were formulated:

i. To what extent the universities integrated entrepreneurship education into the formal curriculum?

ii. What are the main barriers in implementing entrepreneurship education activities in higher education institutions?

\section{Literature Review}

Based on sweeping changes in the global economy and associated changes in the nature of the workplace, it is no longer sufficient for institutions of higher education simply to train students to occupy traditional employment roles (Galloway et al., 2005). Instead higher education institutions should promote both in industrialized and industrializing countries as a mechanism for educating and developing students for an entrepreneurial career and equipping them with the necessary skills and competences to compete in a rapidly globalizing marketplace (Nabi \& Holden, 2008).

It is becoming clear that entrepreneurship is the engine driving the economy and society of most nations (Carree \& Thurik, 2003). Although entrepreneurship is not a new concept, it has gained increasing interest and research attention over the past 15 years; today entrepreneurship is considered the essential lever to cope with the new competitive landscape (Hitt \& Reed, 2000). There are a number of reasons, such as the fact that entrepreneurship is perceived as bringing benefits at both the macro level of economic development 
(Izquierdo \& Buelens, 2008) and also at the micro level of personal satisfaction and achievement (Anderson, Kirkwood \& Jack, 1998).

Nowadays, higher education institutions have an important role in the improvement of entrepreneurship, being part of an entrepreneurial ecosystem with business and government. The market labor faced many changes in last year's, the unemployment rates increased and the possibility of creation a firm comes as an important way to add value to economy and to create jobs. In this environment, universities and colleges must provide entrepreneurship education, develop and adapt competencies, skills, disseminate knowledge, technology and increase economic development as well as help students to create new firms and provide the adequate set of training to manage them across their life cycle (Volkmann et al, 2009). As a result, the academic institutions and their programs have been called upon to provide more substantial impact on developing and stimulating entrepreneurial skills, knowledge and attitudes.

Parallel to the evolution of the field of entrepreneurship we can note an increasing interest in the development of educational programs to encourage and foster entrepreneurship (Solomon, Duffy \& Tarabishy, 2002). Recent studies by Thompson (2009) show that the demand for entrepreneurship faculty has increased remarkably during the last decade. Moreover, the spread of this enterprise culture has brought about academic interest in supporting this new emphasis, calling for much research to be carried out into what makes an entrepreneur and how these characteristics may best be imparted. An international debate on entrepreneurship education has flourished, focusing on several issues.

One of the debates is that entrepreneurship cannot be taught. Scholars such as Brockhaus (1994) stated that teaching someone to be an entrepreneur is like teaching someone to be an artist. We cannot make a person an artist, but he can be taught about colors and composition, and his artistic skills can be improved. Similarly, we cannot make a person creative, but the skills and creativity needed for being a successful entrepreneur could nevertheless be anyway enhanced by entrepreneurship education.

On the other hand, the other wing of debate states that entrepreneurs can be made (Henry, Hill \& Letch, 2005). Taking the words of Drucker (1985:29) as cited in Gibs (2006) who is one of the leading management thinkers of our time stated that .It's not magic, it's not mysterious, and it has nothing to do with the genes. It's a discipline. And, like any discipline, it can be learned.. In this sense, entrepreneurs can be taught and schools have an important role in this process. Following Kuratko (2005), an entrepreneurial perspective can be developed in individuals.

Nevertheless, very few studies have shown proof of these convictions (McMullan, Chrisman \& Vesper, 2001). One example is given by Hansemark (1998), who measured the level of Need for Achievement and Internal Locus of Control, the two main personal characteristics of entrepreneurs, before and after an entrepreneurship course. A statistically significant increase in these two features thanks to the participation in entrepreneurship programs was found. In addition, in another study such as Peterman and Kennedy (2003) found that attendance at an entrepreneurship program has positive effects on both the desirability and the feasibility of starting a business; changes in perceptions are related to the positiveness of prior working experience and of entrepreneurship programs.

Therefore, the majority of the experts indicate that entrepreneurship is teachable (Henry, Hill \& Letch, 2005) integrative (Hannon, 2006), and needed on all levels of education and walks of life (Gibb, 2006). Since entrepreneurship is perceived as behavior patterns (which are thought) it can be influenced from an early age through experiences, family, education, or cultural imprinting.

Taking this point of view scholar such as Alvarez and Busenitz (2004), if universities do not offer entrepreneurship education, students will be less likely to become entrepreneurs. In fact, Peterman and Kennedy (2003) found evidence that students' entrepreneurial experiences during their education awaken or strengthen their desire to create new businesses. If universities promote entrepreneurship education and engage in developing entrepreneurial potential and the different skills related to it (Gibb, 2006); they can raise consciousness and interest in exploring alternative forms of work and entrepreneurial activities.

Even if students do not plan on having their own businesses, they can benefit from the development of entrepreneurial knowledge and skills. Entrepreneurship education not only helps students learn to run a 
business but, more importantly, helps develop creative thinking, innovative capacity, and improvement in self-esteem and responsibility (Heinonen, Kovalainen \& Pukkinen, 2006), which makes it highly desirable.

\section{Reserch and Methodology}

\section{Research design}

In order to examine the nature of integration of entrepreneurship education in Ethiopian universities formal curriculum cross-sectional survey research design was used. This research design was used because it is used to describe characteristics that exist in a population, but not to determine cause-and-effect relationships between different variables which go in line with the purpose of this study.

\section{Population, sample and sampling techniques}

The population of this study is all public universities of the country. From the total universities of the country sample universities were selected from first generation and second generation universities, the third generation universities are excluded because most of them are young and have not completed their developmental stage as a result have no adequate resource and qualified and experienced staffs. In Ethiopia universities are grouped based on their years of establishment that is generation. Hence based on stratified sampling technique 2 universities from first generation (that is Jimma University, and Bahirdar University) and three from second generation (Mezan-Teppi University, and Debre Markos University) were included as sample universities. By simple random sampling technique.

From these sample universities departments that give entrepreneurship course and all department heads, all students who took the course and the instructors that give this course were taken as sample of the study by using availability sampling techniques. Thus, the following table shows the total number of participants (both students and teachers) in each sample universities.

Table 1: Numbers of sample participants

\begin{tabular}{|l|l|l|l|l|}
\hline No. & University & No. of students & No. of Instructors & No. of Dep't heads \\
\hline 1 & Debere Markos University & 190 & 6 & 1 \\
\hline 2 & Bahir Dar University & 154 & 8 & 3 \\
\hline 3 & Jimma University & 220 & 10 & 2 \\
\hline 4 & Mizan Tepi University & 244 & 4 & 1 \\
\hline & Total & 808 & 28 & 7 \\
\hline
\end{tabular}

\section{Instrument of data collection}

Questionnaires: In order to assess the status of entrepreneurship education in Ethiopian universities structured survey questionnaires were developed and administered to selected sample public universities in Ethiopia. It was prepared for students and instructors. Generally, the questionnaires were designed in a way that would help the researcher extract detailed data about the current practice of entrepreneurship education in the universities.

Interview: Semi-structured interview guide question was prepared based on the review of literature. Interview was conducted with the department heads on how the entrepreneurship course is integrated in the formal curriculum of higher education institutions.

Document Analysis: Basic documents such as curricula and entrepreneurship course syllabi (objectives, content, teaching methods and student evaluation methods employed for entrepreneurship courses) of the universities were examined.

\section{Pilot testing of the instrument}

To maintain the validity and reliability of the instrument a pilot testing was conducted by selecting one college in Jimma University. After preparing the instruments it was given for two experts from education in college, Jimma University to check the validity of the items and comments were incorporated. Then the instruments 
were prepared and administered to sample university teachers and students and then the results were processed through SPSS. The reliability coefficient of the instrument was calculated to be (.83) which is regarded as strong correlation by Jackson (2009). Then the final instruments were administered to all sample students and teachers by the researchers and enough time was given for them to fill and return.

\section{Methods of data analysis}

The data collected were analyzed based on the nature of the data:

Quantitative data collected were analyzed by using descriptive statistics such as by the use of frequency, percentage and other descriptive statistics. On the other hand, qualitative data collected through the use of interview, and documents analysis were transcribed, coded based on themes and described qualitatively through the use of word narrations to substantiate the quantitative data.

\section{Emprical Findings}

In order to develop students entrepreneurship behavior, skill, mindset, knowledge and experience on students, one of the strategies is to integrate entrepreneurship education in the curriculum. Since the purpose of providing entrepreneurship education course for the student is to reach students to create awareness of entrepreneurship. As a result, one of the objectives of this study is to see whether the entrepreneurship courses are integrated and taught in the existing curriculum or not.

However, before looking at how the entrepreneurship education is integrated into the curriculum it is a good idea to see some general information about the practice of entrepreneurship education in the universities understudy such as when did this course was started to be offered, the universities practice on entrepreneurship education, the type of entrepreneurship education offered and when is it given in the university program. Therefore, to assess the current practice of entrepreneurship education in higher education of Ethiopia university instructors were requested and the result is presented below.

Table 2: Teachers plan and the university experience in providing entrepreneurship education

\begin{tabular}{|c|c|c|c|}
\hline No. & Item & \# & $\%$ \\
\hline \multirow[t]{4}{*}{1} & $\begin{array}{l}\text { Do you plan any in-curricular activities focusing on the development of } \\
\text { entrepreneurial behavior, skills, knowledge, mindsets, and experiences? } \\
\text { A. Yes }\end{array}$ & & \\
\hline & B. No & 16 & 57.1 \\
\hline & & 12 & 42.9 \\
\hline & Total & 28 & 100 \\
\hline \multirow[t]{6}{*}{2} & $\begin{array}{l}\text { For how many years (including the present academic year) has your university been } \\
\text { provided entrepreneurship education? }\end{array}$ & 2 & 7.1 \\
\hline & A. less than 1 year & 6 & 21.3 \\
\hline & в. between 1 and 5 years & 8 & 28.6 \\
\hline & c. between 6 and 10 years & 4 & 14.3 \\
\hline & $\begin{array}{l}\text { D. between } 11 \text { and } 15 \text { years } \\
\text { E. don't know }\end{array}$ & 8 & 28.6 \\
\hline & Total & 28 & 100 \\
\hline
\end{tabular}

As it is indicated in Table 2 just a slightly above the average number of respondents $16(57.1 \%)$ confirmed that they have a plan in-curricular activities focusing on the development of entrepreneurial behavior, skills, knowledge, mindsets, and experiences for their students. Whereas, 12 (42.9\%) of the respondent instructors replied that they do not have such plan. This result indicated that most of the teachers who teach this course are ready to develop the students' entrepreneurship mindset. Similarly, instructors were asked to indicate for how many years entrepreneurship education is given in their university including the present academic year. As shown in the same table most of the instructors, specifically $8(28.6 \%)$, indicated that entrepreneurship education has been given in their university between 1 and 5 years. This means that they are in the emergent phase of the process. Likewise, the same percentage of respondents affirmed that it is given between 11and 15 years. This could mean that activities and process are well implemented and those institutions could 
provide and share their experience. They could also play an important role as consultants to the emergent programs. Moreover, this variation in response of the respondent instructors might be attributed to the variation in the establishment of the universities. Since this study took respondents from two different generation universities. In addition, instructors were asked what type of program their university offer related to entrepreneurship education, whether all students take entrepreneurship education, and if they took it are they credited to their degree regardless of to which faculty/discipline they belong and their response is presented in Table 3.

Table 3: University entrepreneurship program

\begin{tabular}{llll}
\hline S.No & Item & $\#$ & $\%$ \\
\hline 1 & Did your university offer one or more degree program in entrepreneurship & & \\
& (irrespective of study level) in the previous academic year (s)? & \\
A. Yes & - & - \\
& B. No & 24 & 85.7 \\
& C. I do not know & 4 & 14.3 \\
\hline & Total & 28 & 100 \\
\cline { 2 - 5 } 2 & Do all students at your university take entrepreneurship courses? & & \\
& A. Yes & 2 & 7.1 \\
& B. No & 20 & 71.4 \\
& C. I do not know & 6 & 21.4 \\
\hline & Total $\quad 28$ & 100 \\
\hline
\end{tabular}

As it is indicated in the Table 3 above, most of the instructors 24 (85.7\%) confirmed negatively to the question whether their university offer one or more degree program in entrepreneurship (irrespective of study level) in the previous academic year (s). Whereas, the rest of them replied that they do not have any information about this. Similarly, department heads were interviewed on the same issue; one of the respondents stated that .as far as I know there is no university in this country that offers a degree in the entrepreneurship education.. The above result shows that the university do not offer any degree program that focus on entrepreneurship education. The second item on the same table asks the respondent instructors to confirm whether or not all their university students took entrepreneurship education, as indicated in the table a great majority of instructors $20(71.4 \%)$ affirmed that all students do not take the course entrepreneurship education. On the other hand, only $2(7.1 \%)$ of the respondents replied they took the course.

To confirm the instructors' response students were asked about the practice of entrepreneurship education and their response is presented in the Table 4.

Table 4: The type of entrepreneurship courses students take

\begin{tabular}{|c|c|c|c|c|c|}
\hline \multirow[t]{2}{*}{ No } & \multirow[t]{2}{*}{ Item } & \multicolumn{2}{|c|}{ Student } & \multicolumn{2}{|c|}{ Instructor } \\
\hline & & \# & $\%$ & \# & $\%$ \\
\hline \multirow[t]{6}{*}{1} & How many entrepreneurship courses did you took? & & & & \\
\hline & A. 1 course & 734 & 91.5 & 14 & 58.3 \\
\hline & B. 2 courses & 18 & 2.2 & 6 & 25 \\
\hline & C. 3 courses & 28 & 3.5 & 2 & 8.3 \\
\hline & D. More than 3 courses & 22 & 2.7 & 2 & 8.3 \\
\hline & Total & 802 & 100 & 24 & 100 \\
\hline \multirow[t]{5}{*}{2} & What type of entrepreneurship courses did you took? & & & & \\
\hline & A. Courses about entrepreneurship & 396 & 49.5 & 12 & 46.2 \\
\hline & B. Courses for entrepreneurship & 136 & 17 & 4 & 15.4 \\
\hline & C. Courses both for and about entrepreneurship & 268 & 33.5 & 10 & 38.7 \\
\hline & Total & 800 & 100 & 26 & 100 \\
\hline
\end{tabular}

Participants of the study (both students and instructors) were requested how many course students took in their stay in the university related to entrepreneurship education and as indicated in Table 4 most student $734(91.5 \%)$ and $14(58.3 \%)$ of instructors attested that they take one course that focus on the 
entrepreneurship education. To substantiate this result department heads were requested how many course related to entrepreneurship education their department curriculum incorporated and they confirmed there is only one course in a curriculum related to entrepreneurship education .

Participants were also requested to indicate the type of entrepreneurship courses they took. Most of the students $396(49.5 \%)$ and $12(46.2 \%)$ of instructors replied that students took a courses about entrepreneurship. On the other hand, a significant number of the participant that is $268(33.5 \%)$ of students and $10(38.7 \%)$ of the instructors confirm that students take a courses both for and about entrepreneurship.

Supporting the above result document analysis of the course outline also showed that the contents included are the ones that focus on courses about entrepreneurship. This result shows that the goal is to reach all students to create awareness of entrepreneurship; and to provide the students with an entrepreneurial mindset and or to give the students practical tools to start up new businesses.

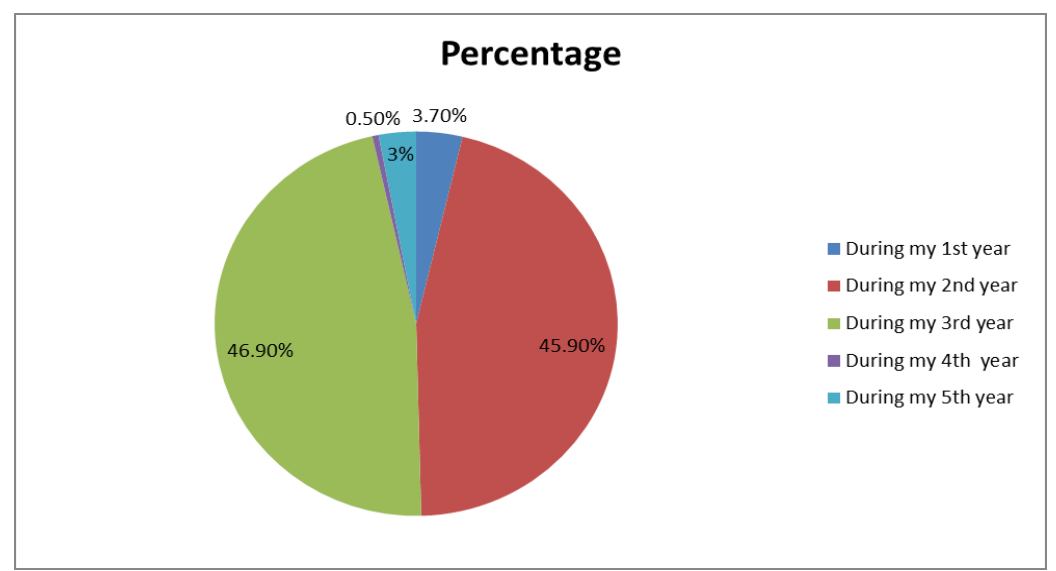

Figure 1: The year of taking entrepreneurship education

As it is indicated in Figure 1 students were asked when you took the entrepreneurship education courses and their response shows that $45.9 \%$ confirm that they took it when they are second year students. Almost a similar proportion of respondents $46.9 \%$ replied that they took is when they are third year students. From this result one can understand that the entrepreneurship education courses is given either in second year or third year that is towards graduation to create awareness and start up business when they graduate.

One of the methods for integrating entrepreneurship education in a curriculum is giving recognition to entrepreneurship courses. In other words, if the course are credited to the degree in which students are involved, it is more likely that the demand for courses will be higher and consequently a better output could be reached. To assess to what extent entrepreneurship education is given recognition in a curriculum both students and instructors were requested the question how these entrepreneurship courses are provided? And their response is presented in Figure 2. 
Tarekegne \& Gelaneh / International Journal of Research in Business and Social Science,

Vol 8 No 2, 2019 ISSN: 2147-4486

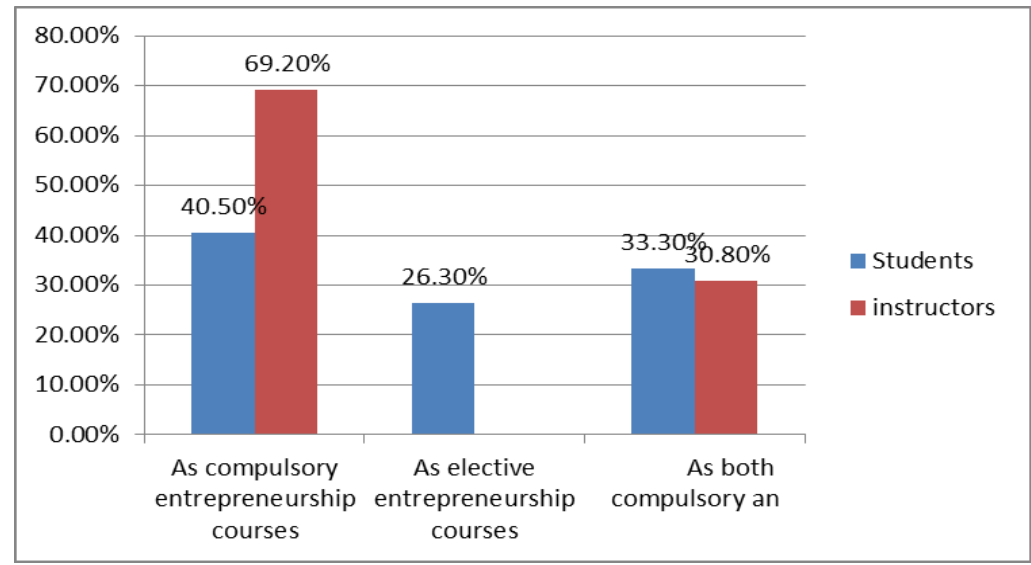

Figure 2: The way entrepreneurship courses are provided

Figure 2, illustrates the response of students to the question how entrepreneurship courses are provided in the Ethiopian higher education. Most of participants both students $40.5 \%$ and instructors $69.2 \%$ reported that students take entrepreneurship courses as compulsory. Whereas, significant number of students $33.3 \%$ and $30.8 \%$ of the instructors believe that they took entrepreneurship courses both as compulsory and elective. From this result it is clear that entrepreneurship education is given recognition both by instructors as well as students.

Another component of the curriculum is method of teaching to teach this course. The methods of teaching, teachers use greatly determines the students achievement of the desired objectives, because teaching methods in reality are fundamental to entrepreneurship education. To investigate the major methods of teaching instructor use to teach entrepreneurship education, students were asked and the response is summarized below in Table 5 .

Table 5: Main teaching methods in the entrepreneurship education class

\begin{tabular}{|c|c|c|c|c|c|c|c|c|c|}
\hline \multirow[t]{2}{*}{ No. } & \multirow[t]{2}{*}{ Methods } & \multicolumn{2}{|c|}{ Often } & \multicolumn{2}{|c|}{ Sometimes } & \multicolumn{2}{|c|}{ Rarely } & \multicolumn{2}{|c|}{ Never } \\
\hline & & \# & $\%$ & \# & $\%$ & \# & $\%$ & \# & $\%$ \\
\hline 1 & Lecturing & 532 & 66.8 & 164 & 20.9 & 60 & 7.7 & 36 & 4.6 \\
\hline 2 & Case studies & 116 & 15.1 & 398 & 51.7 & 142 & 18.7 & 112 & 14.5 \\
\hline 3 & Entrepreneurs in the class room & 110 & 14.2 & 184 & 23.8 & 152 & 19.7 & 326 & 42.2 \\
\hline 4 & Project works & 132 & 17.1 & 316 & 40.8 & 172 & 22.2 & 154 & 19.9 \\
\hline 5 & Company visits & 34 & 4.4 & 126 & 16.3 & 116 & 15.0 & 496 & 64.2 \\
\hline 6 & Venture simulation/mini companies & 32 & 4.2 & 136 & 17.8 & 138 & 18.1 & 458 & 59.9 \\
\hline 7 & $\begin{array}{l}\text { Bringing students from different departments } \\
\text { to mix in the classroom }\end{array}$ & 60 & 7.8 & 124 & 16.1 & 100 & 13.0 & 488 & 63.2 \\
\hline
\end{tabular}

Table 5 depicts the response of students who took the course entrepreneurship education about the most common methods instructors use to teach this course. Accordingly, entrepreneurship instructors in Ethiopian public universities dominantly use lecture $532(66.8 \%)$ method in a class to teach this course. The next commonly used method is case study $398(51.7 \%)$ and project works $316(40.8 \%)$ sometimes.

In the same table it is also made clear that instructors never use the teaching methods that give practical experience to the students such as company visits 496, (64.2\%), venture simulation 458 (59.9), entrepreneurs in the class room $326(42.2 \%)$, and bringing students from different departments to mix in the classroom 488(63.2\%). To corroborate the above result the course outline was analyzed and under the methods of teaching strategies included are lecture and independent reading. In addition, the assessment methods included in the course outline are examinations, tests and quizzes, and business plan reports are the most used methods. From these results it is clear that the major teaching methods and assessment techniques used by entrepreneurship instructors in Ethiopian universities are the traditional methods such 
as business as usual. Likewise, department heads were interviewed on the major methods teachers use to teach this course; for instance one of the department head replied that .I think instructors use the usual lecture method but what is different is in the projects they give to their students. They sometimes provide practical works like preparing business plan, otherwise they use the same method like other courses..

The best method of teaching to develop students entrepreneurship skill is inviting guest lecturers or practitioners with practical experience as entrepreneurs since he/she has a practical experience to share for the students. The students may be motivated by the practitioner and may be initiated to create a job related to their profession. To see to what extent the Ethiopian higher education instructors use practitioners as lecturers on entrepreneurship education students were asked and the responses to the participants this clearly indicate that a relatively significant number of respondents $326(42.2 \%)$ confirmed that their instructors never used guest lecturers or practitioners with practical experience as entrepreneur to make the training more practical. On the other hand, a significant number of students $184(23.8 \%)$ affirmed that their instructors sometimes invited guest lecturers. The development of entrepreneurship education has been a huge focus for Education Institutions in the past years. Nevertheless, there are barriers to be crossed in order to develop and provide quality in-curricular activities focused on fostering entrepreneurial mindsets, attitudes and skills. In other words, there are a lot of challenges that might hinder the dissemination of entrepreneurship courses, programs and activities in higher education, and/or the effectiveness of this type of education. The sample students and instructors were asked to identify existing challenges and their response is presented in the Table 6.

Table 6: The barriers to entrepreneurship education

\begin{tabular}{|c|c|c|c|c|c|c|c|c|c|}
\hline \multirow{3}{*}{ No. } & \multirow[t]{3}{*}{ Barriers to Entrepreneurship } & \multicolumn{4}{|c|}{ Student } & \multicolumn{4}{|c|}{ Instructor } \\
\hline & & \multicolumn{2}{|c|}{ Apply } & \multicolumn{2}{|c|}{ Not apply } & \multicolumn{2}{|c|}{ Apply } & \multicolumn{2}{|c|}{ Not apply } \\
\hline & & \# & $\%$ & \# & $\%$ & \# & $\%$ & \# & $\%$ \\
\hline 1 & $\begin{array}{l}\text { No support from the government/policy environment } \\
\text { for entrepreneurship education needs improving }\end{array}$ & 394 & 54.1 & 334 & 45.9 & 20 & 76.9 & 6 & 23.1 \\
\hline 2 & $\begin{array}{l}\text { No funding available to support the entrepreneurship } \\
\text { education }\end{array}$ & 422 & 57.8 & 308 & 42.2 & 26 & 100 & - & - \\
\hline 3 & $\begin{array}{l}\text { There is no academic credibility in entrepreneurship } \\
\text { education }\end{array}$ & 394 & 54.6 & 328 & 45.4 & 10 & 38.5 & 16 & 61.5 \\
\hline 4 & $\begin{array}{l}\text { There is a lack of good-quality entrepreneurship } \\
\text { education materials }\end{array}$ & 456 & 62.1 & 278 & 37.9 & 20 & 76.9 & 6 & 23.1 \\
\hline 5 & No support from the top management at my institution & 376 & 51.8 & 350 & 48.2 & 24 & 92.3 & 2 & 7.7 \\
\hline 6 & $\begin{array}{l}\text { At my institution no recognition is given for excellence } \\
\text { in entrepreneurship education }\end{array}$ & 356 & 49.3 & 366 & 50.7 & 22 & 84.6 & 4 & 15.4 \\
\hline 7 & $\begin{array}{l}\text { The entrepreneurship education lacks strategic } \\
\text { integration at my institution }\end{array}$ & 382 & 52.6 & 344 & 47.4 & 22 & 84.6 & 4 & 15.4 \\
\hline 8 & $\begin{array}{l}\text { The entrepreneurship education depends on the } \\
\text { efforts of a single person/a few people }\end{array}$ & 438 & 60.5 & 286 & 39.5 & 20 & 71.4 & 6 & 23.1 \\
\hline 9 & $\begin{array}{l}\text { Some of the academic staff oppose the introduction } \\
\text { of entrepreneurship education }\end{array}$ & 418 & 57.4 & 310 & 42.6 & 8 & 30.8 & 18 & 69.2 \\
\hline 10 & $\begin{array}{l}\text { Limited expertise among academic staff/current level } \\
\text { of educator competence is inadequate }\end{array}$ & - & - & - & - & 18 & 69.2 & 8 & 30.8 \\
\hline 11 & $\begin{array}{l}\text { Academic staff /students does not have enough time } \\
\text { to engage in entrepreneurship education }\end{array}$ & - & - & - & - & 10 & 38.5 & 16 & 61.5 \\
\hline 12 & $\begin{array}{l}\text { No demand for entrepreneurship education from the } \\
\text { students }\end{array}$ & 332 & 45.7 & 394 & 54.3 & 2 & 7.7 & 24 & 92.3 \\
\hline
\end{tabular}

As shown in Table 6, students and instructors were reported major barriers for the implementations of entrepreneurship education. The first barrier identified by the students $(57.8 \%)$ and instructors $(100 \%)$ is lack of funding available to support the entrepreneurship education. The resource dimension of the survey 
showed that most institutions supported entrepreneurship education through short-term funding, thereby limiting the degree of commitment institutions place on developing a cohesive entrepreneurship education framework on campus. Another barrier that is frequently rated by the participant students and which is related with lack of funding is lack of good-quality entrepreneurship education materials (62.1\%).

Similarly, the responses of the department heads confirms the existence of the above challenge; for instance one of the respondent confirmed that .As far as I know there is no special fund to support entrepreneurship education in my university this is I feel one of the bottleneck to promote entrepreneurship education in the university..

The second most common barrier was lack of support from the top management at their institution, as indicated by students $(51.8 \%$ ) and by instructors $(92.3 \%)$. From this result it is clear that the strategic barriers for entrepreneurship education is lack of support from top management and outside stakeholders, and that it is a challenge to motivate management and make them understand the approach.

The third most common barrier was a lack of strategic integration of entrepreneurship education in their institutions, which is rated by students $(52.6 \%)$ and $(84.6 \%)$ by instructors. Two of the three most common barriers among institutions were strategic in nature, suggesting the need among management to acknowledge entrepreneurship education and commit to deliver it across campus.

\section{Discussion}

The study investigates the integration of entrepreneurship education in Ethiopian public universities in the formal curriculum that focus on departmental distribution of entrepreneurship courses, the objectives and areas of focus and the major teaching methods employed.

The existing literature shows that within the field of entrepreneurship education is in its infancy in many parts of the world and by many institutions. In addition, much of the curriculum is based on experience from the United States and cannot be directly transferred to a local context. There should therefore be good opportunities for institutions to learn from each other, both in developing curriculum and teaching methods. However, unlike other European countries the results of this study indicate that in Ethiopian higher education entrepreneurship education curriculum and/or teaching methods is developed in house.

The study revealed that though entrepreneurship courses are offered in all Ethiopian public universities, the distribution of the courses is not uniform. In other words, all students do not take the course. The courses are predominantly offered in the college of business and economics. Research however suggests the need to incorporate the course not only in business and economics colleges but also in natural science faculties and in engineering. According to Kok (2004), entrepreneurship education should be incorporated into the non-business disciplines of engineering and science where product ideas emerge but are often ignored because students are not sufficiently educated in the knowledge and skills required for start-ups. Some researchers also suggest the need to offer entrepreneurship courses to graduates of all disciplines regardless of major or faculty. Streeter and Jaquette (2004), for example argue that the core objective of university-wide programs is to extend the opportunity of entrepreneurship education to all students in the university, regardless of their faculty or subject major.

In Ethiopian context as this study made clear in all departments in which entrepreneurship course is offered, they are offered only for one semester as a single course. In addition, entrepreneurship education is not offered in one or more degree program in itself. The effectiveness of this type of one shut and short period exposure to entrepreneurship education is doubtful. Friedrich and Visser (2004) argue that short training courses in entrepreneurial training as found in business schools, do not have the same results as found in training courses of longer duration. According to them, a long period of time is required to influence the attitude towards entrepreneurial career especially in larger groups.

The effectiveness of entrepreneurship education with such objectives and focus is not expected to produce graduates with good entrepreneurial orientations. This is because the course focuses on the functional aspects of the (Co \& Mitchell, 2006), who classified entrepreneurship education as education about entrepreneurship and education for entrepreneurship, cast entrepreneurship education aiming at developing, 
constructing and studying the theories referred to the entrepreneurs, the firm creation, the contribution of entrepreneurship to economic development, the entrepreneurial process and the small and middle sized firms as education about entrepreneurship. And entrepreneurship education in Ethiopian public universities largely falls in the category of education about entrepreneurship rather than education for entrepreneurship.

Research supports the need for entrepreneurship courses to focus on developing the right attitudes and motivation for start-up; providing the technical abilities and skills needed to develop a business; fostering networks and contacts for entrepreneurial ventures; achieving the sharp intuition to act at the correct moment; and attaining the knowledge base and information for new venture development (Katz, 2004). Therefore, the objectives of entrepreneurship education in universities should be revisited and developed in such a way that it can enable graduates acquire skills and competencies needed to initiate new venture and manage and sustain a newly established business rather than merely focusing on the functional understanding of entrepreneurship.

As far as the teaching methods are concerned, the study has shown that class lecture by instructors followed by case study and preparation assignment/project is the commonly used teaching methods. Guest speakers who are prominent entrepreneurs and visit to prominent entrepreneurs' work places are rarely used methods in Ethiopian universities. The heavy presence of the traditional methods of teaching can be attributed to two possible reasons. One of the reasons could be the fact that the teachers are general business and management educators with little special training in what and how to teach and assess entrepreneurship course. And the other reason could be the fact that the teachers are not suitably qualified and experienced in their career.

Like any other activity the development of entrepreneurship education is affected by different barriers. In other words, there are a lot of challenges or obstacles that might hinder the dissemination of entrepreneurship courses, programs and activities in higher education, and/or the effectiveness of this type of education.

Accordingly, the results of this study revealed that the one of the most common barriers is lack of funding available to support the entrepreneurship education. It is clear that the level and scope of entrepreneurship education is closely linked to the amount of resources available for entrepreneurship education. So there is a natural barrier related to the amount of resources that the university is able to direct to the undertaking of entrepreneurship education.

Another barrier identified in this study is lack of support from top management and from outside stakeholders. This result is also consistent with the findings of Kuratko (2005) that indicate low support from the management body is a hindrance for the development of entrepreneurship education. It is a challenge to motivate management and make them understand the approach. The understanding might be easier to find for entrepreneurship education in the traditional sense whereas entrepreneurship education in technical or other specialized areas can be harder to get across. There is a problem of awareness and motivation within the institutions, when entrepreneurship is a priority neither for administration nor for faculties. In most cases, research publications are seen as being far more important. Therefore entrepreneurship within an institution is very much dependent on the willingness and vision of certain leaders. This is not an organizational problem, but rather a strategic one. Lastly another barrier identified is lack of strategic integration of entrepreneurship education in their institutions. Generally we can say that two of the three most common barriers among institutions were strategic in nature, suggesting the need among management to acknowledge entrepreneurship education and commit to deliver it across campus.

\section{Conclusion}

Based on the results of the study the following conclusions are drawn:

The findings reveal that at the strategy level, all the educational institutions that are offering entrepreneurship education have entrepreneurship goals. The most common goal among Educational Institutions is to foster entrepreneurial skills and mindsets among students. Educational institutions should put more focus on this matter as the development of entrepreneurship education is very close related to this. 
The objectives of entrepreneurship course did not focus towards the improvement of the attitude of graduates towards self-employment, risk taking as well as skills needed to manage and run newly created businesses. On the other hand, the method of teaching used is the traditional teaching methods which are not action or practical oriented approach that help students give an opportunity to practice or hands on activity.

A better accreditation and recognition of the courses and activities will encourage students to join and give their best to the benefit of institutions and society. The findings show that entrepreneurship is not a high priority for higher education institutions in Ethiopia and the goal of having entrepreneurship education embedded in the few disciplines curriculum could mean that the integration of entrepreneurship into education is not on the right path.

As Ethiopia needs the young generation to create new ventures and provide innovation and entrepreneurial thinking in the existing business, educational institutions need to overpass the barriers they face in providing education and coaching for the young entrepreneurs in a way that the new and innovative ideas do not get lost. The main barriers stated by the survey participants are the lack of funding to support the entrepreneurial activities; the entrepreneurship education depends on the efforts of individuals/few people and the lack of expertise from the academic staff. Another barrier is lack of support from the top management. The lack of quality materials is also a barrier that the educational institutions are facing. This could mean that entrepreneurship is heading to a mature stage, where the collaboration between top management and lecturers should be the focus point and actions towards strengthening the collaboration have to be taken.

\section{References}

Alvarez, S. A., \& Busenitz, L. W. (2004). The entrepreneurship of resource-based theory. Journal of Management, 27, 755-775.

Anderson, A. R., Kirkwood, S. and Jack, S. L. (1998). Teaching Entrepreneurship: A Mentoring

Experience. Paper presented at Babson Conference, Belgium.

Brijlal, P. (2008) .The state of entrepreneurship education at tertiary institutions in the Western Cape. Journal of College Teaching \& Learning (TLC), Vol. 5 No. 2, pp. 25-36.

Brockhaus, R. (1994). Entrepreneurship Education and Research Outside North America. In Hoy, F., Brock, W. A. and Evans, D.S. (1989). Small Business Economics. Small business economics, 1, 7-20.

Carree, M. A., Thurik, A. R. (2003), The Impact of Entrepreneurship on Economic Growth. In

Acs, Z.J., Audretsch D. B. (eds.) Handbook of Entrepreneurship Research: An Interdisciplinary Survey and Introduction. Kluwer Academic Publishers :Boston, 437-471.

Co, M.J. and Mitchell, B. (2006) .Entrepreneurship education in South Africa: a nationwide survey. Education \&Training, Vol. 48 No. 5, pp. 48-359.

Friedrich C \& Visser K 2004. South African Entrepreneurship Education and Training. De Doorns: Leap Publishing.

Galloway, L., Anderson, M., Brown. W., \& Wilson, L. (2005). Enterprise skills for economy. Education and Training, 47, 7-17.

Ghelawdewos Araia(2012), Reflections on the Development of Higher Education in Ethiopia: Africanldea.org (accessed on august.20, 2013) .

Gibb, Allan (2006). Entrepreneurship / Enterprise Education in Schools and Colleges:Are we really building the onion or peeling it away? National Council for Graduate Entrepreneurship Working Paper, 039/2006; pp.1-34

Hannon, Paul, D. (2006.) Teaching pigeons to dance, Education and Training, Vol. 48; No.5. pp. 296-308 
Tarekegne \& Gelaneh / International Journal of Research in Business and Social Science, Vol 8 No 2, 2019 ISSN: 2147-4486

Hansemark, Ove. (1998). The Effects of an Entrepreneurship Programme on Need for Achievement and Locus of Control of Reinforcement. International Journal of Entrepreneurial Behaviour \& Research 4 (1): $28-50$.

Heinonen, J., Kovalainen, A., \& Pukkinen, T. (2006). Global entrepreneurship monitor,executive report Finland. Turku school of economics and business administration, series B2/2006.

Henry, C., Hill, F. and Leitch, C. (2005) .Entrepreneurship Education and Training: Can Entrepreneur be Taught? Part I., Education and Training Journal, Vol. 47, Issue 2, pp.98-111.

Hitt, M. A. \& Reed, T.S. (2000). Entrepreneurship in the new competitive landscape. In: Entrepreneurship as Strategy. (eds) Meyer, G.D. \& Heppard, K.A. Thousand Oaks: Sage Publications.

Isaacs, E., Visser, K., Friedrich, C. and Brijlal, P. (2007) .Entrepreneurship education and training at the Further Education and Training (FET) level in South Africa. South African Journal of Education, Vol. 27 No. 4, pp. 613-29.

Jackson L. S. (2009). Research methods and statistics a critical thinking approach. New York: Wadsworth

Izquierdo, E. \& Buelens, M. (2008). Competing models of entrepreneurial intentions: the influence of entrepreneurial self-efficacy and attitudes. USA: Ohio

Kabongo, J.D. and Okpara, J.O. (2010).Entrepreneurship education in sub-Saharan African

Universities. International Journal of Entrepreneurial Behavior \& Research, Vol. 16 No. 4, pp. 296-308.

Katz, J.A. (2004). Survey of Endowed Positions in Entrepreneurship and Related Fields in the United States, Ewing Marion Kauffman Foundation, Kansas City, MO.

Kok, W. (2004) .Kok Report. report of an independent high-level expert group, headed by formed Dutch Prime Minister Wim Kok, presented to European Commission and the European Council, November.

Kuratko, D. (2005). The Emergence of Entrepreneurship Education: Development, Trends, and Challenges. Entrepreneurship Theory and Practice, p, 577-597

McMullan, W. E., Chrisman, J.J. and Vesper, K. H. (2001). Some problems in using subjective measures of effectiveness to evaluate entrepreneurial assistance programs. Entrepreneurship Theory and Practice, 26 (1), 37-54.

Ministry of Education [MOE] (2008). National Technical \& Vocational Education and Training Strategy, Addis Ababa, Ethiopia

Ministry of Education [MOE] (2015). Education Sector Development Program IV (ESDP V), Addis Ababa, Ethiopia

Nabi, G. and Holden, R. (2008). Graduate entrepreneurship: intentions, education and training. Education \&Training, Vol. 50 No. 7, pp. 545-51.

Peterman, N.E. and Kennedy, J. (2003). Enterprise Education: Influencing Students' Perception of Entrepreneurship. Entrepreneurship Theory and Practice, 28(4), 129-141.

Solomon, G.T., Duffy, S. and Tarabishy, A. (2002). The State of Entrepreneurship Education in the United States: a Nationwide Survey and Analysis. International Journal of Entrepreneurship Education 1(1), 1-22.

Thompson, E.R. (2009). Individual entrepreneurial constructs clarifications and development of an internationally reliable metric. Entrepreneurship Theory and Practice, May, 669-694.

Volkmann, C., Wilson, K., Mariotti, S., Rabuzzi, D., Vyakarnam, S., Sepulveda, A. (2009).Educating the Next Wave of Entrepreneurs Unlocking entrepreneurial capabilities to meet the global challenges of the 21st Century - A Report of the Global Education Initiative., World Economic Forum, Switzerland, April 2009. 